\title{
PELATIHAN PEMBUATAN HANDSHOAP, DETERJEN DAN SABUN CUCI PIRING UNTUK MENINGKATKAN KESEHATAN DAN PEREKONOMIAN MASYARAKAT DESA KETAPANG RAYA PADA MASA PANDEMI COVID-19
}

\author{
Siti Nurhidayati ${ }^{1}$, Khaeruman $^{2}$, Diah Lukitasari $^{3}$ \\ ${ }^{1}$ Pendidikan Biologi, ${ }^{2}$ Pendidikan Kimia, ${ }^{3}$ Manajemen \\ Universitas Pendidikan Mandalika \\ Email: sitinurhidayati328@gmail.com
}

\begin{abstract}
Abstrak: Sabun merupakan kebutuhan utama masyarakat, terutama Tujuan pengabdian ini adalah membelajarkan masyarakat agar memiliki pengetahuan dan keterampilan dalam membuat handsoap, deterjen cair dan sabun cuci piring untuk meningkatkan kesehatan dan perekonomian masyarakat pada masa pandemic covid 19. Melalui pelatihan ini masyarakat mampu membuat sendiri sabu cuci tangan, deterjen cair dan sabun cuci piring yang sangat dibutuhkan untuk meningkatkan kebersihan baik diri maupun lingkungan dalam rangka menjaga kesehatan pada masa pandemic covid19, selain itu masyarakat juga mampu membuka usaha kecil untuk menjual handsoap, deterjen cair dan sabun cuci piring untuk meningkatkan perekonomian.
\end{abstract}

Kata Kunci: Handsoap, Deterjen, Sabun_Cuci_Piring, Kesehatan_Masyarakat, Covid-19.

\section{PENDAHULUAN}

Desa Ketapang Raya merupakan salah satu desa yang berada di Kecamatan keruak Kabupaten Lombok Timur dan termasuk desa terdampak Covid-19. Selain itu masyarakatnya juga enggan keluar rumah untuk menghindari tertular Covid-19, akan tetapi berdampak pada perekonomian masyarakat. Masyarakat dihimbau untuk menjaga kebersihan tubuh, pakaian atau peralatan yang digunakan dengan dicuci menggunakan sabun dan menjaga jarak.

Sabun merupakan salah satu kebutuhan utama masyarakat untuk mendapatkan standar kebersihan pada kehidupan sehari-hari, akan tetapi termasuk dalam kebutuhan sekunder (Wardani, 2019). Kebutuhan akan sabun terus meningkat, baik berupa sabun tangan (handsoap), deterjen cair dan sabun cuci piring terutama di masa pandemic Covid-19, harga pun meningkat.

Untuk itu telah dilakukan pelatihan kepada masyarakat berupa pelatihan pembuatan handsoap, deterjen cair dan sabun cuci piring untuk meningkatkan kesehatan dan perekonomian masyarakat pada masa pandemic covid 19. Handsoap, deterjen cair dan sabun cuci piring merupakan kebutuhan yang sangat penting, terutama pada saat ini, dimana sedang mewabahnya covid-19, masyarakat harus sering mencuci tangan pakai sabun, mencuci pakaian terutama setelah dipakai keluar rumah, mencuci semua peralatan makan sebelum dipakai menggunakan sabun untuk meningkatkan Kesehatan masyarakat. Selain itu masyarakat dapat berwirausaha menjual handsoap, deterjen cair dan sabun cuci piring ke masayarakat luas untuk meningkatkan perekonomian. Pelatihan seperti ini dapat meningkatkan pengetahuan dan keterampilan masyarakat dalam pembuatan sabun yang dapat digunakan pribadi maupun dikomersilkan (Haro, dkk, 2017; Amalia, dkk, 2018); Nasution dan Zebua, 2019).

\section{METODE}

Pengabdian ini berupa pelatihan pembuatan handsoap, deterjen cair dan sabun cuci piring untuk meningkatkan kesehatan masyarakat pada masa pandemic covid 19. Metode pelaksanaan yang dilakukan dalam pengabdian ini berupa pelatihan yang terbagi dalam beberapa tahapan diantaranya: 1). sosialisasi cara pembuatan handsoap, deterjen cair dan sabun cuci piring dengan membagikan panduan pembuatan ke tiga item kepada masyarakat, 2). Mengenalkan alat dan bahan yang digunakan, 3). Pelatihan dan 
Pendampingan masyarakat dalam percobaan pembuatan handsoap, deterjen cair dan sabun cuci piring. 5). Pengemasan produk menggunakan botol plastic yang sudah dilabeli merek.

\section{HASIL DAN PEMBAHASAN}

Pengabdian ini dilaksanakan di Desa Ketapang Raya Kecamatan Keruak Kabupaten Lombok Timur pada bulan Juni 2020 guna meningkatkan kesadaran masyarakat pentingnya menjaga kebersihan tangan, pakaian dan peralatan yang digunakan untuk menjaga Kesehatan masyarakat agar terhindar dari covid 19. Adapun tahap kegiatan yang dilakukan ialah:

1. Sosialisasi

Sosialisasi pelatihan ini dilakukan untuk memberikan gambaran tentang cara pembuatan handsoap, deterjen cair dan sabun cuci piring kepada masyarakat dengan membagikan panduan pembuatan ke tiga item kepada masyarakat.

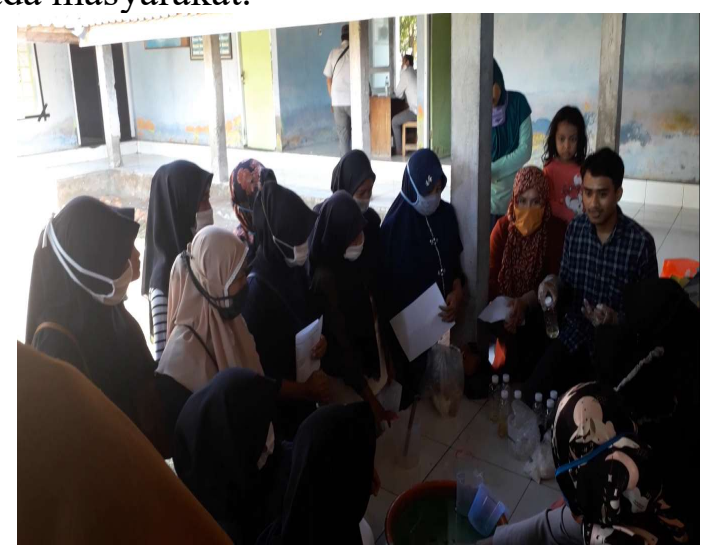

Gambar 1. Sosialisasi pembuatan handsoap, deterjen cair dan sabun cuci piring

2. Mengenalkan alat dan bahan yang digunakan,

Ada beberapa alat dan bahan yang digunakan dalam pembuatan handsoap, deterjen cair dan sabun cuci piring. Alat-alat yang digunakan misalnya: gelas ukur, pipet, bak, pengaduk, gelas besar, sendok, botol, gunting, label dan tissue, sedangkan bahan-bahan yang digunakan (Tim Penyusun, 2019) berupa: texafon yang merupakan bahan dasar semua sabun, sampo ataupun deterjen, sodium sulfat, metain untuk mengontrol busa, glucotain untuk menghilangkan noda, minyak dan pengesat.

Selain itu ditambahkan pewarna, pewangi, air bersih. Bahan-bahan ini digunakan untuk membuat handsoap. Deterjen cair dan sabun pencuci piring menggunakan bahan dasar yang sama dengan handsoap, akan tetapi perlu ditambahkan LABS dan soda ash untuk menghilangkan noda membandel pada pakaian dan peralatan makan.

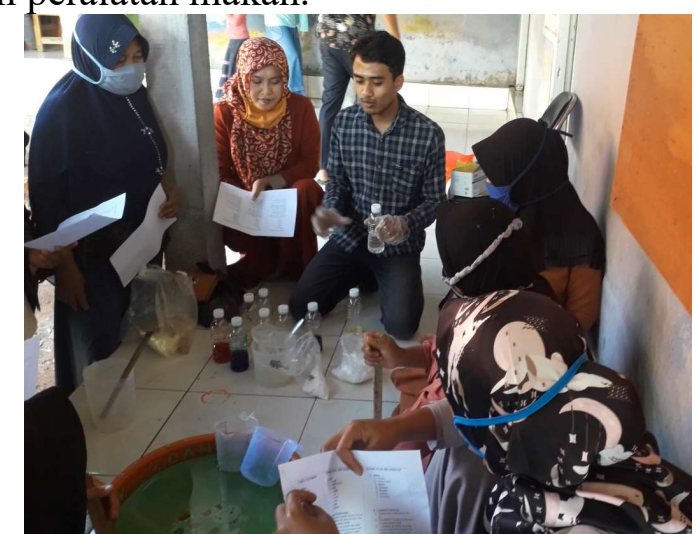

Gambar 2. Pengenalan alat dan bahan pembuatan handsoap, deterjen cair dan sabun cuci piring 
3. Pelatihan dan pendampingan masyarakat dalam percobaan pembuatan handsoap, deterjen cair dan sabun cuci piring.

Masyarakat diberi pelatihan dan pendampingan cara membuat handsoap, deterjen cair dan sabun cuci piring. Adapun Langkah-langkah pembuatan handsoap (Tim Penyusun, 2019) adalah sebagai berikut: 1) menyiapkan wadah dengan ukuran $500 \mathrm{ml}, 2$ ). Memasukkan 50 gr texafon dan 25 gr sodium sulfat, 3). Menambahkan air bersih sedikit demi sedikit sambal diaduk rata, 4). Menambahakan $5 \mathrm{ml}$ metain dan $2 \mathrm{ml}$ glucotain, 5). Menambahkkan pewarna dan pewangi, 6) menambahkan air hingga mencapai kekentalan yang sempurna. Untuk pembutan deterjen cair dan sabun pencuci piring, Langkah pembuatannya sama dengan pembuatan handsoap, hanya saja ditambahkan $5 \mathrm{ml}$ LABS dan soda ash secukupnya.

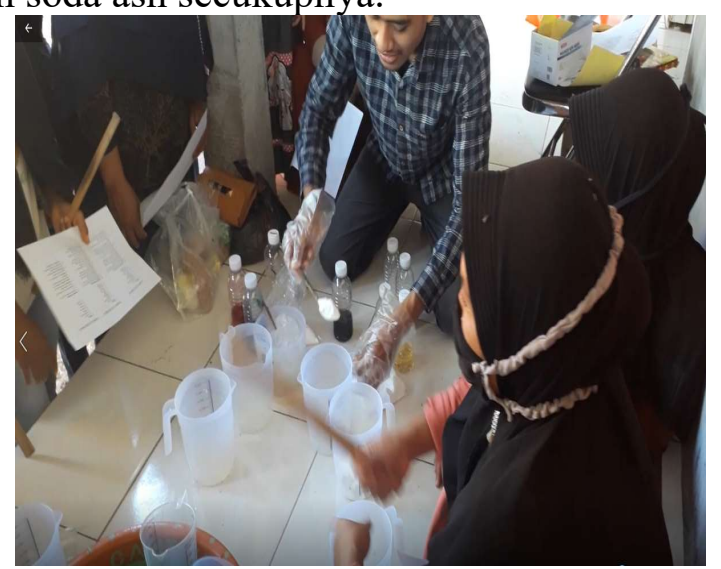

Gambar 3. Demonstrasi pembuatan handsoap, deterjen cair dan sabun cuci piring

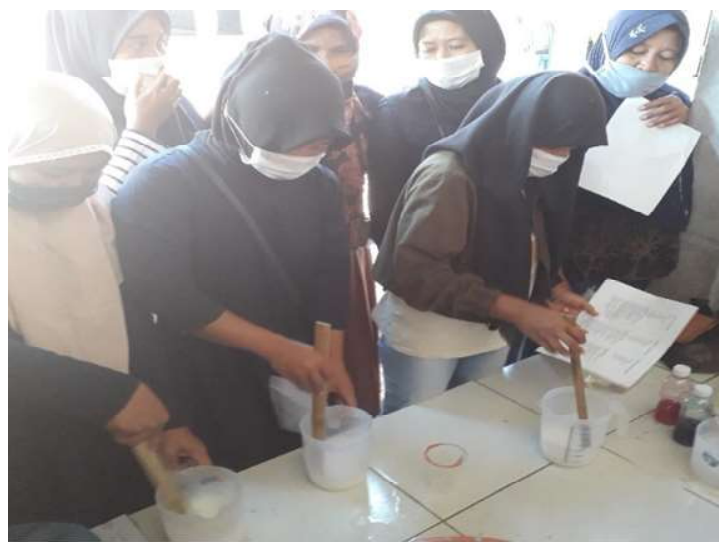

Gambar 4. Pelatihan dan pendampingan pembuatan handsoap, deterjen cair dan sabun cuci piring

4. Pengemasan produk menggunakan botol plastic yang sudah dilabeli merek.

Produk yang dihasilkan dari pelatihan ini berupa cairan yang perlu dikemas agar bisa disimpan di jual. Cairan yang dihasilkan ini dikemas menggunakan botol plastic yang sudah diberi label handsoap, deterjen cair dan sabun cuci piring. Produk ini ramah lingkungan dapat digunakan secara luas oleh masyarakat. Masyarakat dapat meningkatkan pendapatan keluarganya dengan berwirasaha produk-produk yang ramah lingkungan (Usep dan Sholehudin, 2019) 


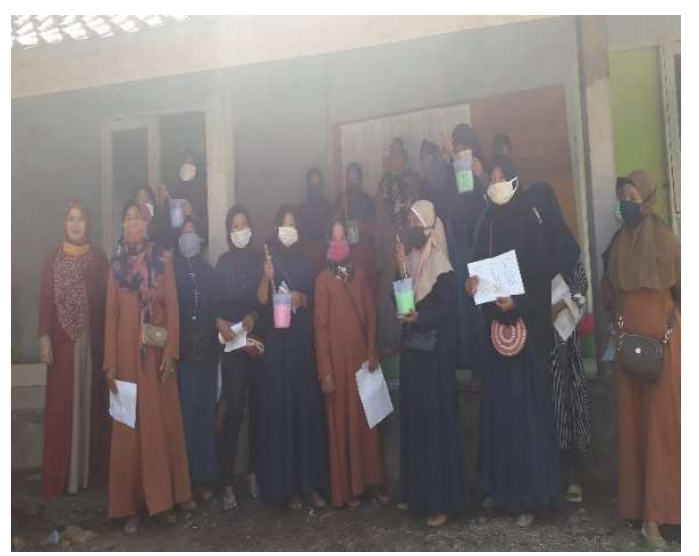

Gambar 5. Simbolis Penyerahan Alat pembuatan handsoap, deterjen cair dan sabun cuci piring.

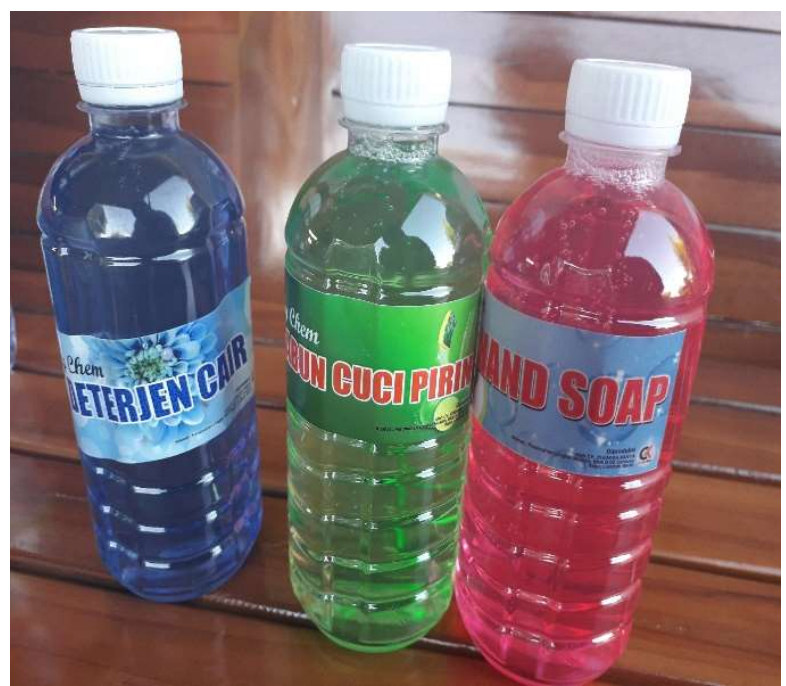

Gambar 6. Produk (Handsoap, Deterjen, sabun cuci piring)

Handsoap yang dihasilkan berupa sabun cair untuk cuci tangan yang dapat menghilangakan kotoran dan kuman, berwarna merah muda dengan aroma mawar, Sabun cair juga dapat ditambahkan dengan aroma terapi yang dapat memberikan efek terapi, kesegaran dan wangi yang khas yang dapat merelaksasi pikiran jika menghirupnya (Marjanah, dkk, 2019) atau ditambahkan komoditas lokal misalnya tomat dan kopi (Widyasanti, dkk, 2016), sedangkan deterjen cair yang dihasilkan berupa sabun cuci baju yang mampu menghilangkan kotoran dan keringat pada pakaian, berwarna biru dengan aroma sakura.

Selain itu, sabun cuci piring yang dihasilkan mampu membersihkan peralatan makan dan terasa kesat, berwarna hijau dengan aroma jeruk nipis. Handsoap, deterjen cair dan sabun cuci piring yang dihasilkan dapat digunakan secara langsung oleh masyarakat guna memenuhi kebutuhan sabun pada rumah tangga masing-masing atau dapat dikomersialkan dengan cara dipasarkan kepada masyarakat sekitar untuk menambah pendapatan keluarga untuk meningkatkan kesehatan dan perekonomian masyarakat pada masa pandemi covid- 19 .

\section{KESIMPULAN}

Handsoap, deterjen cair dan sabun cuci piring yang dihasilkan dapat digunakan oleh masyarakat, baik secara pribadi untuk mencuci tangan, mencuci pakaian dan mencuci peralatan makan ataupun dapat dikomersialkan guna meningkatkan kesehatan dan perekonomian masyarakat pada masa pandemi covid19. 


\section{DAFTAR PUSTAKA}

Amalia, R., Paramita, V., Kusumayanti, H., Wahyuningsih, Sembiring, M., dan Rani, DE. (2018). Produksi Sabun Cuci Piring Sebagai Upaya Peningkatkan Efektivitas Dan Peluang Wirausaha. Metana. 14 (1):15-18

Haro, A., Waspodo, AAWS., dan Handaru, AW. (2017). Peningkatan Keterampilan Bagi Ibu Rumah Tangga dalam Rangka Penghematan Melalui Pembuatan Sabun Cair Sederhana. Jurnal Pemberdayaan Masyarakat Madani (JPMM). 1 (2): 194-206.

Marjanah., Indriaty., dan Setyoko. (2019). Wirausaha Kreatif Pembuatan Sabun Cair Aroma Terapi Bagi Masyarakat Di Birem Rayeuk Aceh Timur. Jurnal Pengabdian Untuk Mu Negeri. 3 (2).

Nasution, HA., dan Zebua, F. (2019). Pelatihan Pembuatan Sabun Cair Cuci Piring Untuk Meningkatkan Keterampilan Kewirausahaan Peserta Didik Di Mas Al-Washliyah Desa Pakam. Jurnal Anadara Pengabdian Kepada Masyarakat. 1 (1): 39-42.

Tim Penyusun (2019). Buku Petunjuk Praktikum Kimia. Laboratorium Kimia Undikma. Mataram.

Usep, HW dan Solahudin (2019). Pelatihan Pembuatan Detergen Cair Ramah Lingkungan di Kampung Cibening, Kota Serang. Intervensi Komunitas Jurnal Pengabdian Masyarakat. 1 (1): 81-86.

Wardani, IK. (2019). Pelatihan Pembuatan Sabun Cuci Piring dan Sabun Detergent Bagi Masyarakat Desa Senyiur Kec. Keruak Lombok Timur. Abdi Masyarakat. 1 (1): 25-28.

Widyasanti, A., Putri, SH., dan Dwiratna SNP. (2016). Upaya Pemberdayaan Masyarakat Melalui Pelatihan Pembuatan Produk Sabun Berbasis Komoditas Lokal Di Kecamatan Sukamantri Ciamis. Dharmakarya: Jurnal Aplikasi Ipteks untuk Masyarakat. 5 (1): 29 - 33. 